Neuro Images
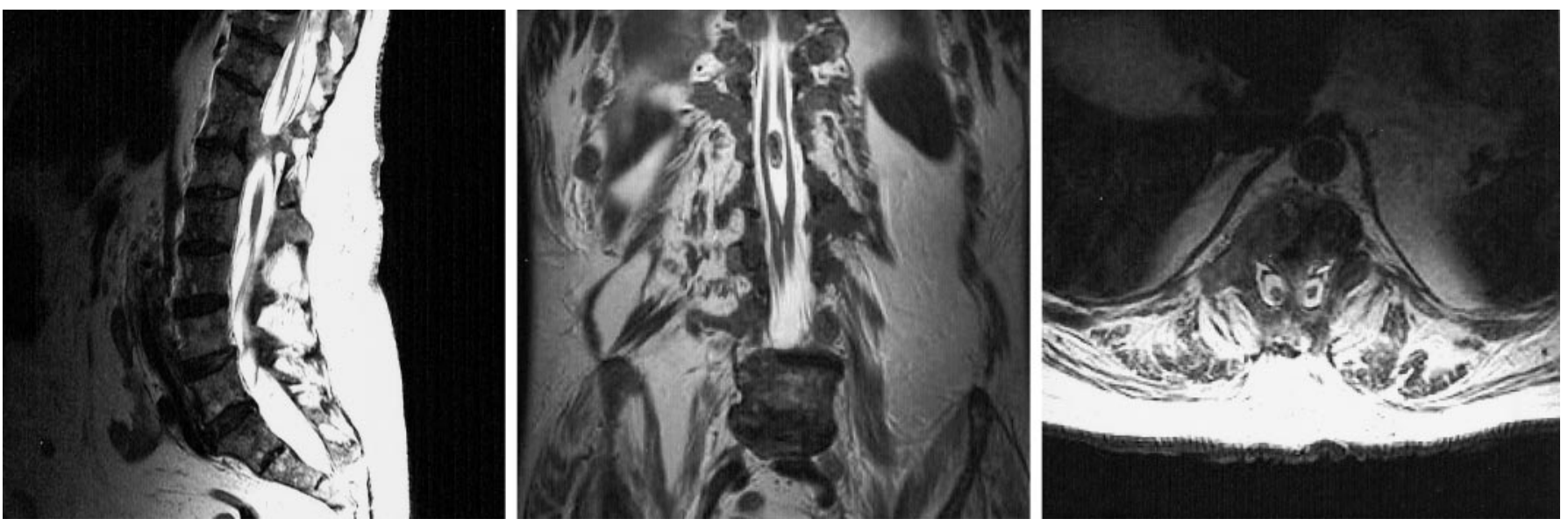

Figure. Diastematomyelia of the spinal cord. Mid-sagittal, coronal, and axial T2-weighted images showing split spinal cord at T12-L1 with bony peg that extends to the posterior lamina and spinous process producing spina bifida. The spinal cord is split from approximately T10 to L3 with tethering of the tip of the conus medullaris at L4.

\section{Split spinal cord (diastematomyelia)}

Hamid Sami, MD, Elliott Ross, MD, Max Walter, MD, Sunil Goli, MD, Oklahoma City, OK

Diastematomyelia is a rare form of spinal dysraphism characterized by a sagittal cleft of varying extent that splits the spinal cord, conus medullaris, or filum terminale with splaying of the posterior vertebral elements. This condition is caused by an osseous, cartilaginous, or fibrous septum, producing a complete or incomplete sagittal divi-

Address correspondence and reprint requests to Dr. Hamid Sami, Department of Neurology, University of Oklahoma Health Science Center, P.O. Box 26901, Suite 215, Oklahoma City, OK 73190; e-mail: hamid-sami@ouhsc.edu sion of the spinal cord into two hemicords. ${ }^{1}$ It may be isolated or associated with other segmental anomalies of the vertebral bodies. Patients may have neurologic deficits in the lower limbs and perineum, causing gait disorders, sphincter disturbances, muscular atrophy, reflex changes, congenital scoliosis, and foot deformities. With modern imaging techniques, spinal dysraphism is being diagnosed in adults with increasing frequency, often as an incidental finding. ${ }^{2}$ The figure shows MRIs of a patient with clinically silent diastematomyelia.

1. Prasad VS, Sengar RL, Sahu BP, Immaneni D. Diastematomyelia in adults. Modern imaging and operative treatment. Clin Imaging 1995;19: $270-274$.

2. Linn RM, Ford LT. Adult diastematomyelia. Spine 1994;19:852-854. 


\section{Neurology}

Split spinal cord (diastematomyelia)

Hamid Sami, Elliott Ross, Max Walter, et al.

Neurology 2003;60;491

DOI 10.1212/01.WNL.0000044730.82558.AC

This information is current as of February 11, 2003

\section{Updated Information \&} Services

References

Permissions \& Licensing

Reprints including high resolution figures, can be found at: http://n.neurology.org/content/60/3/491.full

This article cites 2 articles, 0 of which you can access for free at: http://n.neurology.org/content/60/3/491.full\#ref-list-1

Information about reproducing this article in parts (figures,tables) or in its entirety can be found online at:

http://www.neurology.org/about/about_the_journal\#permissions

Information about ordering reprints can be found online: http://n.neurology.org/subscribers/advertise

Neurology ${ }^{\circledR}$ is the official journal of the American Academy of Neurology. Published continuously since 1951, it is now a weekly with 48 issues per year. Copyright . All rights reserved. Print ISSN: 0028-3878. Online ISSN: 1526-632X.

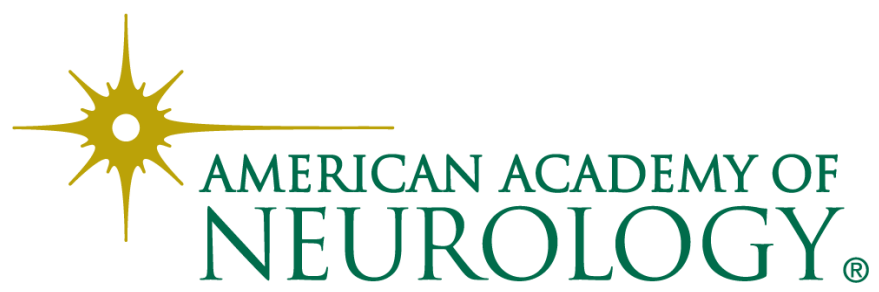

